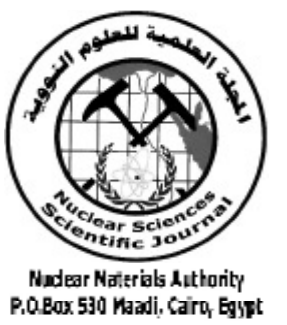

ISSN 2314-5609

Nuclear Sciences Scientific Journal

$6,191-207$

2017

http://www.ssnma.com

\title{
PAN-AFRICAN GRANITOID ROCKS HOSTING JASPEROID VEINS, MASSAK BIRAYKE AREA, NORTH EASTERN DESERT, EGYPT: RADIOACTIVITY AND MINERALOGY
}

\author{
SAID S. FARAG; MOHAMED O. EL-HUSSEINY and SALAH S. EL-BALAKSSY \\ Nuclear Materials Authority, P.O. Box, 530, El-Maadi, Cairo, Egypt
}

\begin{abstract}
The studied granitic rocks are mainly distinguished into granodiorites and syenogranites based on their field relationship and petrography. The syenogranites are unconformably overlain by Nubian sandstones from the west. They exhibit an extensive alteration nearby the jasperoid veins such as ferrugination, sericitization, kaolinization, silicification and black manganese dendritic staining. The mineralized reddish brown jasperoid veins intrude the syenogranites and are mostly observed at the highly fractured parts. Some of these jasperoid veins stained with black and reddish brown $\mathrm{Mn}$ and Fe oxides associated with bright yellow color of secondary uranium minerals.

The radiometric measurements show that the granodiorites and syenogranites exhibits moderate uranium and thorium contents. They display $6 \mathrm{ppm} \mathrm{eU}$ and $15 \mathrm{ppm}$ eTh in average for the first and $19 \mathrm{ppm} \mathrm{eU}$ and $30 \mathrm{ppm}$ eTh for the later. Unlike, the jasperoid veins attains highest values (eU=250 ppm, eTh=72 ppm) in average. The enrichment of $U$ in the jasperoid veins is probably because of mobilization of $U$ from the syenogranite. Detailed microscopic examinations, X-ray diffraction (XRD) and Environmental Scanning Electron Microscope (ESEM) with EDX microanalysis revealed that the presence of secondary uranium minerals as carnotite and uranophane as well as U-bearing accessory minerals such as betafite, samarskite, zircon and violet fluorite are responsible for radioactivity•
\end{abstract}

\section{INTRODUCTION}

The granitic rocks cover large areas in the Eastern Desert and southern Sinai in addition to scattered outcrops in the south western Desert of Egypt. They have been classified in different objects of view. One of them gave weight to relative ages: e.g. El-Ramly and Akaad (1960). They differentiated the Egyptian granitoids into (a) Older granitoids of grey color and tonalitic to granodioritic composition and (b) Younger granites of pink to red color and granitic composition. The emplacement of the older granitoids occurred at about 700-750 Ma (Dixon, 1979). On the other hand, the younger granites occur in the restricted age range of 565-590 Ma (Fullagar and Greenberg, 1978 \& Abdel-Monem and Hurely, 1979). The jasperoid veins are favorable host rocks for various uranium minerals in different occurrences in the Eastern Desert of Egypt. They are associated with granitic plutons of Gabal El Missikat (Abu Deif et al., 2007, Abu Deif and El Tahir, 2008, and Raslan, 2009) and Gabal El Aradiya (Abd El Naby, 2008).

Gabal Massak Birayke is located in the Red Sea mountain ranges to the northwest of Hurghada city between lat. $27^{\circ} 3^{\prime}$ and $27^{\circ} 10^{\prime} \mathrm{N}$ 
and long. $32^{\circ} 51^{\prime}$ and $32^{\circ} 57^{\prime}$ E. Several works are carried out on the study area (Schurmann, 1953; Dardier and Abu Zeid, 1972; Ghanem et al., 1973; Abu El Leil, 1980, Mussa and Abu El Leil 1983, Khamis 1995 and El-Galy et al. 2002). Detailed field geology and petrographical studies were carried out to identify the granitic types exposed in the study area as well as detailed radiometric measurements in these rocks which led to the reconnaissance of radioactive anomalies in the jasperoid veins and surrounded host rocks. On the other hand, the mineralogical studied were done to identify the radioactive minerals that responsible for these anomalies.

\section{FIELD GEOLOGY}

The rock types cropping out in the study area $\left(95 \mathrm{Km}^{2}\right)$ are mainly represented by granodiorites and syenogranites overlain by Nubian sandstones from the west (Fig. 1). The granodiorites outcrop along the northern parts of the

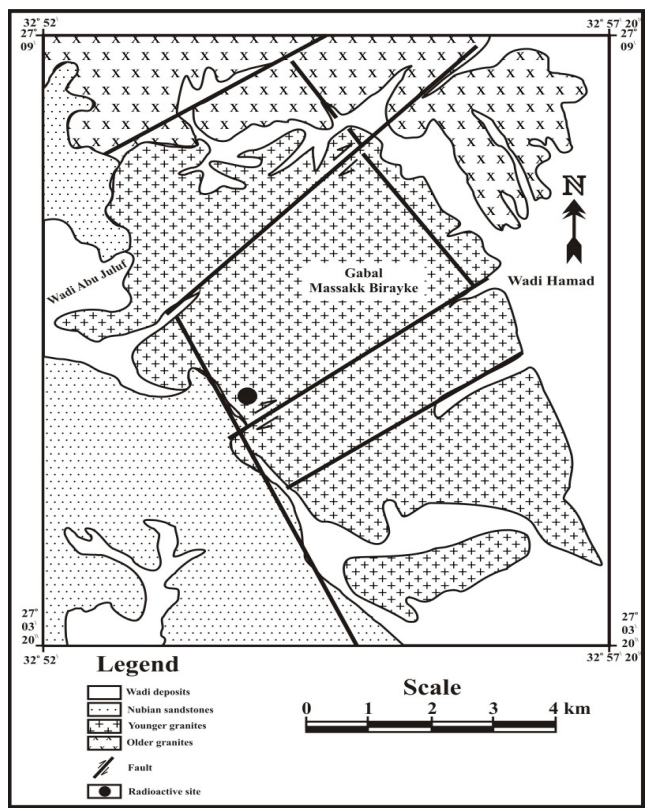

Fig.1 : Geologic map of Massak Birayke area mapped area and extend beyond the limits of the study area. They usually form low-lying hills with gentle slopes. Their topography gets higher along the contacts with the seynogranites. These rocks are whitish grey to dark grey in color and may attain pinkish-grey to reddish-grey colors near the contacts with the younger granites. In hand specimens, they are medium-to coarse- grained, massive, nonporphyritic and show clusters of mafic minerals. They show extensive jointing and exfoliation weathering appearance (Fig. 2) and sometimes, enclose xenoliths of older rocks.

The syenogranites crop out as low to moderate topographic hills. Their specimens are generally equigranular, hard, massive, medium - to coarse-grained and pale pink to pink in color. They intrude the granodiorites with sharp intrusive contacts (Fig. 3) and present as offshoots invading them (Fig. 4). These rocks overlain by Nubian Sandstones from the west. The syenogranitic rocks are well jointed and dissected by faults trending mainly in the NE-SW and NW-SE directions. These highly fractured granites near the faults become highly hematitized and filled by jasperoid veins. These rocks are characterized by abundance of vertical joints. Generally, the studied granitoids, nearby the jasperoid frac-

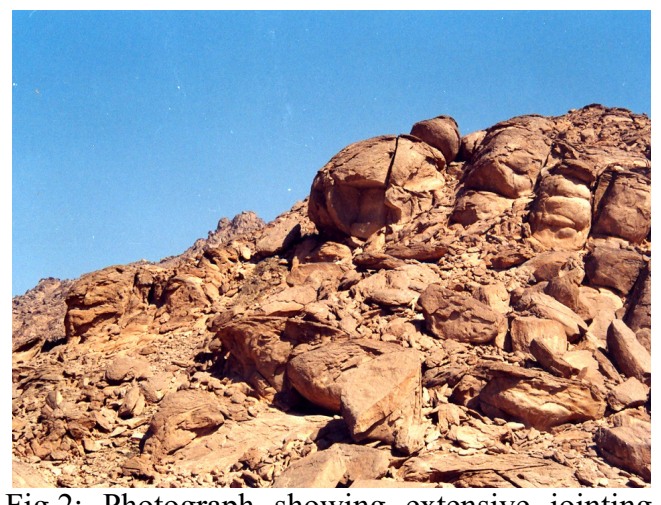

Fig.2: Photograph showing extensive jointing and exfoliation weathering appearance in granodiorites (GD), Wadi Hamad, looking NE 


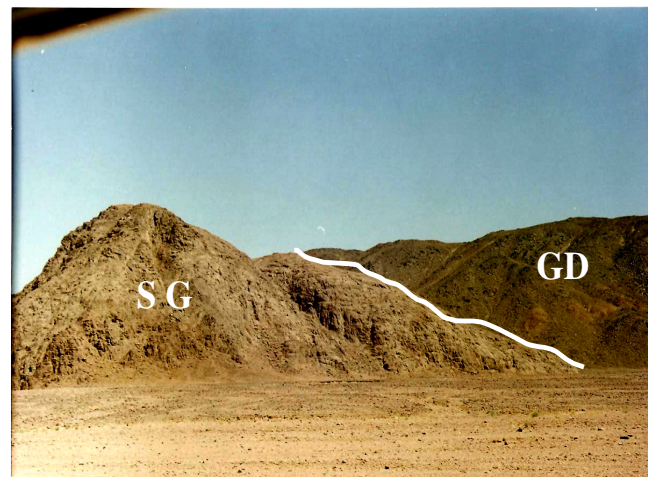

Fig.3: Photograph showing Granodiorites (GD) intruded by syenogranites (SG), Wadi Hamad, looking NW

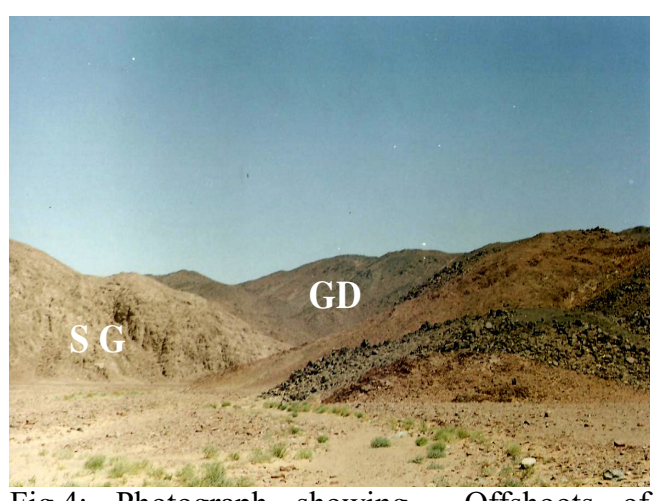

Fig.4: Photograph showing Offshoots of syenogranites $(\mathrm{SG})$ in the granodiorites (GD), looking NE

tured filling veins show different features of hydrothermal alterations represented by ferrugination, silicification, kaolinization, sericitization and dark black dendritic patches of manganese oxides. The emplacement of the studied granites was followed by the intrusion of number of acidic dykes mainly porphyritic microgranite trending in NE-SW direction.

Two generations of siliceous veins were hosted in the studied syenogranites. The first one is the mineralized jasperoid veins (Fig.
5). Jasperoid veins are mostly observed at the highly tectonized parts along fractures in the highly sheared parts and striking mainly in NNW-SSE direction. The mineralized jasperoid veins are irregular in shape and vary in width from $2 \mathrm{~cm}$ to more than $20 \mathrm{~cm}$ and from $5 \mathrm{~m}$ to about $15 \mathrm{~m}$ in length. Generally, jasperoid veins are characterized by massive appearance and stained with reddish brown iron and black manganese oxides cutting through younger granitoids (Fig. 6). Visible bright lemon yellow colored secondary uranium minerals were encountered along microfracture surfaces in these veins and coating cavities and vugs as thin films and fine

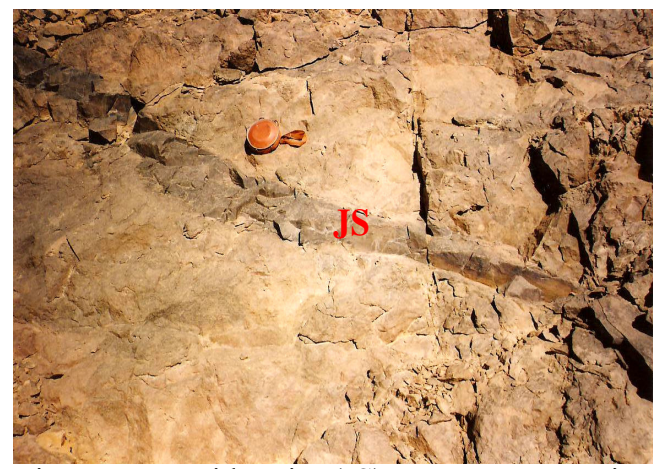

Fig.5: Jasperoid vein (JS) cuts syenogranites (SG), looking NE

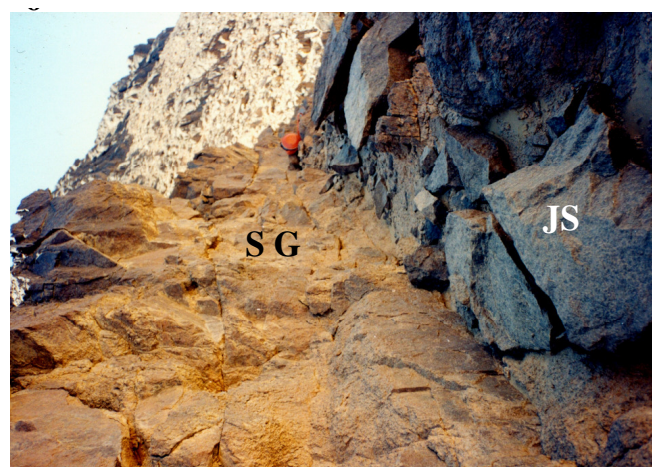

Fig.6: Lemonitized syenogranites (SG) cutting by reddish brown jasperoid vein (JS), looking $\mathrm{N}$ 
clots. These secondary uranium minerals are always found in association with violet fluorite.

The second generation of silicification is the white non-mineralized quartz veins which are striking mainly in NE-SW direction. They vary from $50 \mathrm{~cm}$ to $1.5 \mathrm{~m}$ in width and from $5 \mathrm{~m}$ to about $10 \mathrm{~m}$ in length. In some parts, silica fills fractures in the hosting syenogranites forming intricate and dense networks of relatively short veinlets running mostly in NWSE to NWW-SEE directions. Faults traversing the study area are generally striking in NW-SE and NE-SW directions filled with the jasperoid veins (Fig. 7). These faults are of vertical or steep dips and strike-slipe type. The zones of these faults are relatively wide and characterized by shearing and cataclases of the granitoids.

\section{PETROGRAPY}

The modal composition of 15 representative samples of the studied granitoids (7 samples represent granodiorites and 8 samples represent syenogranites) are given in Table (1). The studied samples are plotted in granodiorite and syenogranite fields according to Streckeisen (1976), (Fig. 8).

Granodiorites are medium- to coarse-

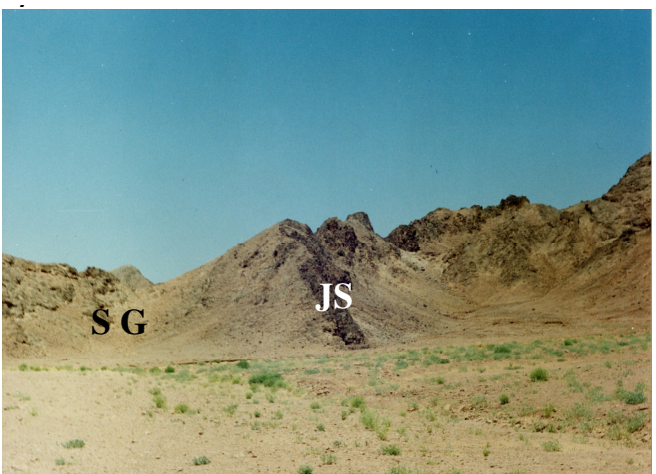

Fig.7: General view showing jasperoid vein (JS) cutting syenogranites (SG), looking $\mathrm{N}$
Table 1: Modal composition of the studied granites

\begin{tabular}{|c|c|c|c|c|c|c|}
\hline Rock type & Quartz & K-felds. & Plagioclase & Hornblende & Biotite & Op.+Acc. \\
\hline \multirow{7}{*}{ 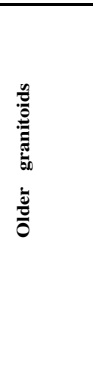 } & 45 & 11 & 30 & $\overline{6}$ & $\overline{4}$ & 4 \\
\hline & 42 & 10 & 33 & 9 & 4 & 3 \\
\hline & 33 & 8 & 40 & 9 & 6 & 4 \\
\hline & 37 & 7 & 42 & 7 & 4 & 3 \\
\hline & 36 & 9 & 39 & 10 & 4 & 2 \\
\hline & 30 & 13 & 42 & 8 & 4 & 3 \\
\hline & 27 & 14 & 45 & 7 & 5 & 2 \\
\hline Average & 36 & 10 & 39 & 8 & 4 & 3 \\
\hline \multirow{8}{*}{ 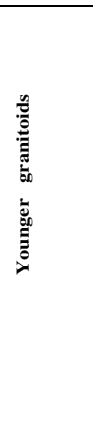 } & 38 & 42 & 16 & - & 2 & 1 \\
\hline & 37 & 40 & 19 & - & 3 & 2 \\
\hline & 35 & 48 & 12 & - & 4 & 0.5 \\
\hline & 35 & 45 & 16 & - & 2 & 2 \\
\hline & 39 & 45 & 14 & - & 1 & 1 \\
\hline & 32 & 47 & 16 & - & 3 & 2 \\
\hline & 36 & 45 & 17 & - & 2 & 0.5 \\
\hline & 36 & 42 & 17 & - & 3 & 2 \\
\hline Average & 36 & 44 & 16 & - & 3 & 1 \\
\hline
\end{tabular}

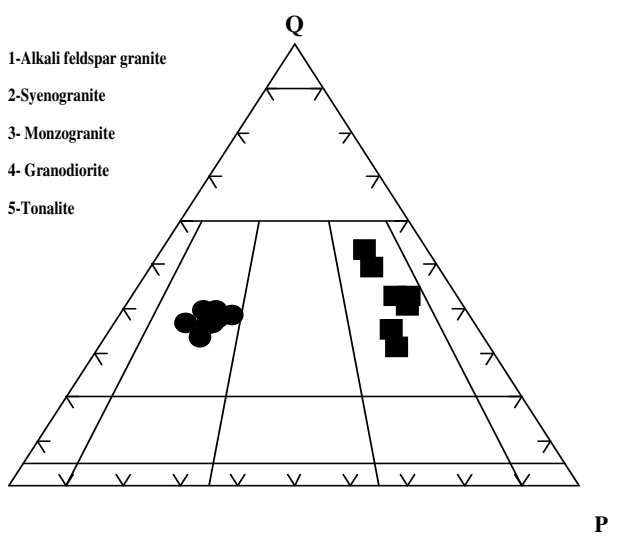

Fig.8: QAP diagram of the studied granitoids, According to Streckeisen (1976) 
grained and whitish grey to dark grey in color. They are composed mainly of plagioclase, quartz, K-feldspars, hornblende and biotite. Opaques and sphene occur as accessory minerals.

The plagioclases (oligoclase, An $25-32$ ) occur as euhedral to subhedral tabular crystals showing albitic and pericline twinning (Fig. 9). Some crystals are cracked due to strain and other ones are partially saussuritized (Fig. 10). Sometimes, zoned plagioclase is occurred. Quartz occurs as medium- to coarse anhedral grained showing undulose extinction. Some

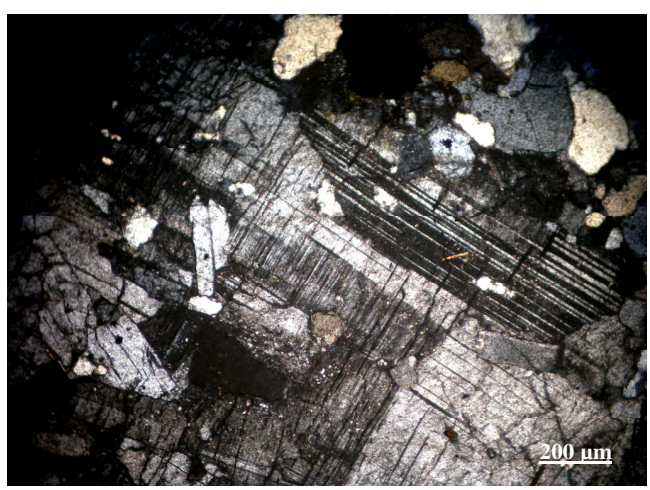

Fig.9: Photomicrograph of euhedral crystal of plagioclase showing percline twining, studied granodiorite,XPL

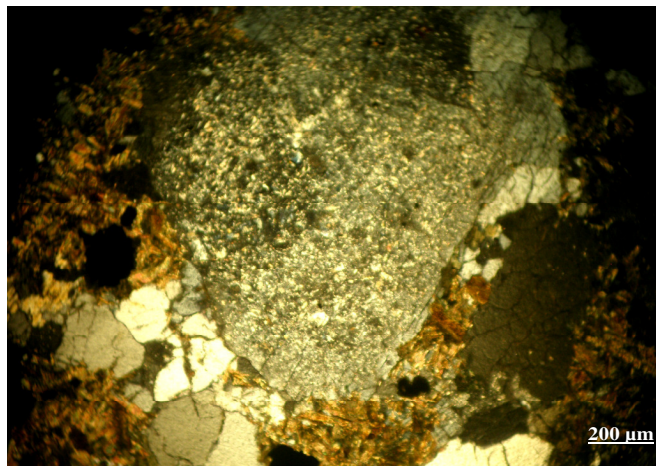

Fig.10: Photomicrograph of plagioclase showing saussuritization, studied granodiorite, XPL crystals are cracked, elongated and stretched due to strain. K-feldspars occur as small subhedral crystals of perthite. They are completely altered to sericite.

Hornblende occurs as coarse euhedral crystals of prismatic shape of green to blue color. In most samples, hornblende altered to biotite. It enclosed appreciable amounts of opaques. Biotite occurs as small subhedral flakes of brown color associated with hornblende. Polysynthetic biotite occurred as a secondary mineral after hornblende (Fig. 11). Some crystals enclosed opaques. Opaques are found either as euhedral crystals of cubic and elongated shape or anhedral to subhedral interstitial crystals. Sphene is present as secondary mineral enclosed in hornblende and associated with opaques (Fig. 12).

Syenogranites consist of K-feldspars, quartz, plagioclases and minor biotite. Zircon and opaques are accessories. K-feldspars occur as subhedral to euhedral crystals of orthoclase perthite. They occur as feather and patchy perthites (Figs. 13\&14). They enclosed small crystals of quartz, zircon and opaques. Some crystals are staining by iron oxides. They are partially altered to sericite. Quartz occurs as coarse-grained with undulose extinction.

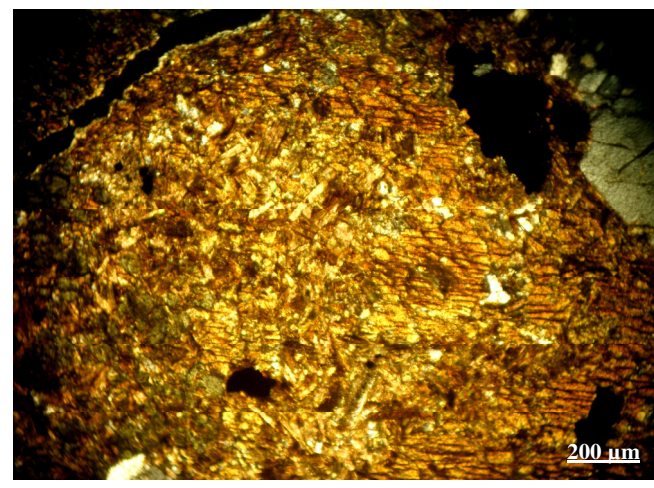

Fig.11: Photomicrograph of Secondary biotite showing polysynthetic texture, studied granodiorite ,XPL 


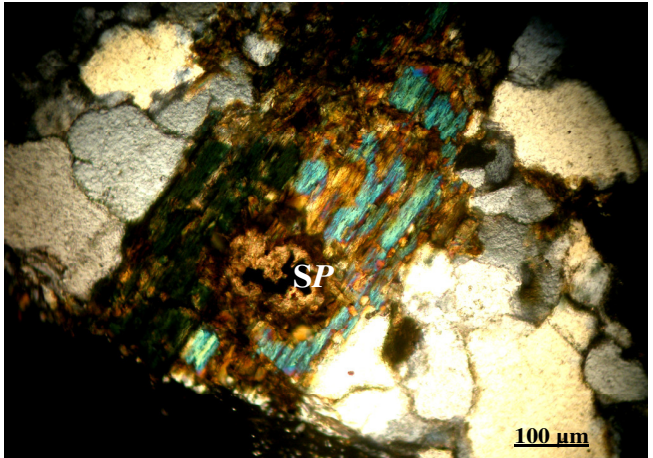

Fig.12: Photomicrograph of secondary sphene (SP) associated with opaques enclosed in hornblende, studied granodiorite, XPL

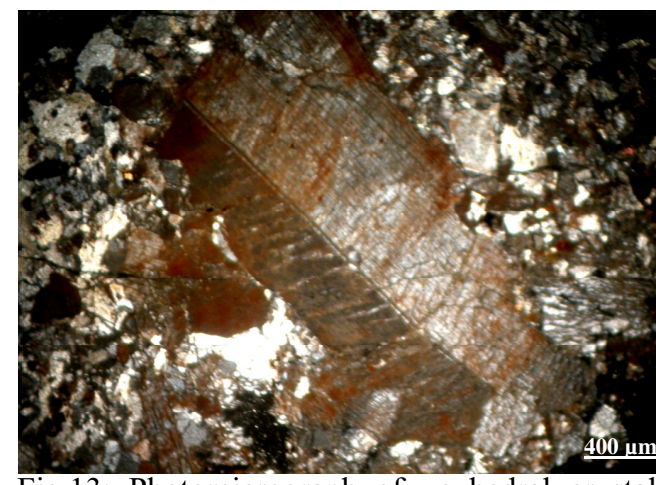

Fig.13: Photomicrograph of euhedral crystal of feather perthite coated by iron oxides in syenogranite, XPL

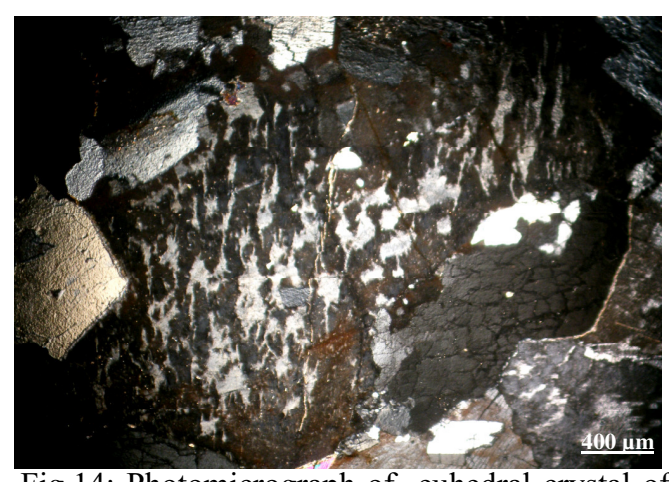

Fig.14: Photomicrograph of euhedral crystal of patchy perthite in syenogranite, XPL
Due to shearing, it is cracked and sometimes occurs as saccaroidal texture. It encloses fine crystals of zircon, perthite and flakes of biotite. Plagioclases $\left(\mathrm{An}_{6-10}\right)$ occur as euhedral crystals of tabular form up to $3 \mathrm{~mm}$ in length showing carlsbad and albitic twinning. Some crystals show indications of strain by having highly deformed lamellae (Fig. 15). They are partially saussuritized. Biotite presents as a minor amount as small flakes of brown color. It is partially altered to muscovite. Zircon occurs as euhedral crystals of prismatic shape. Radioactive zircon surrounded by pleochroic haloes are occurred enclosed in quartz (Fig. 16).

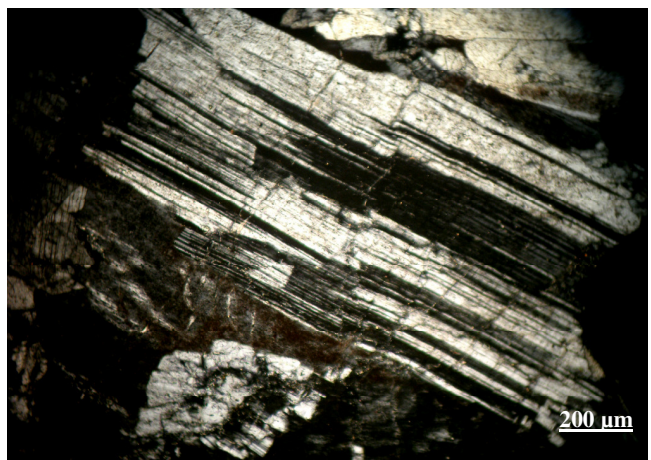

Fig.15: Photomicrograph of deformed crystal of plagioclase in syenogranite, XPL

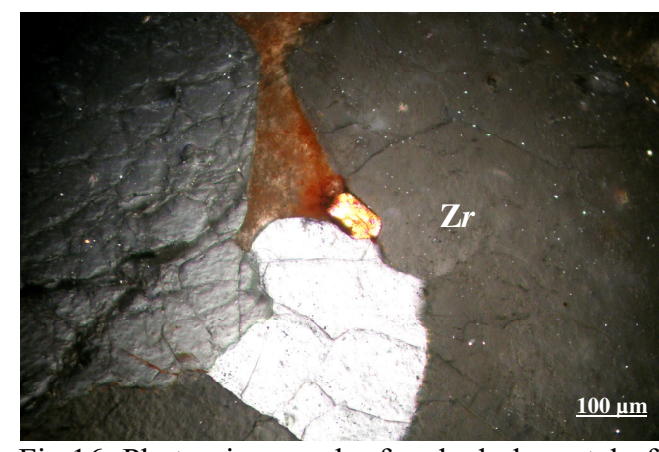

Fig.16: Photomicrograph of euhedral crystal of zircon $(\mathrm{Zr})$ enclosed in quartz in syenogranite, XPL 
Jasperoid veins are composed of cryptocrystalline silica with some very fine crystals of quartz. The common feature of the jasperoid rocks is the presence of cores clouded by tinny hematite inclusions within dominant quartz (Fig. 17). The hematite flakes are too small to display diagnostic optical properties but are identified as such by their bright red internal reflections that are particularly strong when observed in reflected light with crossed polarizers. Quartz grains vary overall size between the samples and range from seriate where closely packed to euhedral when separated by open pores or microcavities. Narrow veinlets of quartz locally cut into or across wallrock fragments. The shapes of wallrock fragments are very irregular. They contain bright yellow radioactive minerals associated with reddish brown iron oxides adsorbed on amorphous silica (Fig. 18).

\section{RADIOACTIVITY}

The radiometric survey of the studied granites is carried out using a gamma-ray spectrometer instrument model (GS-512) which measures the equivalent uranium (eU) and equivalent thorium (eTh) in ppm. The studied granitic rocks as well as all dykes and fracture filling veins in the study area were radio-

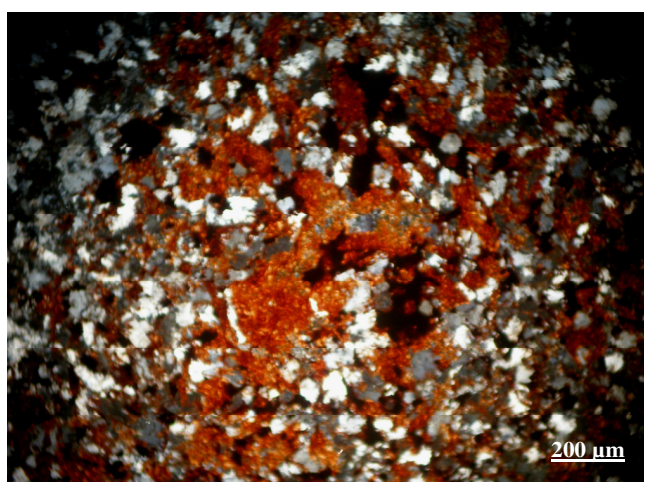

Fig.17: Photomicrograph of cryptocrystalline quartz stained by iron oxides in jasperoid vein, XPL

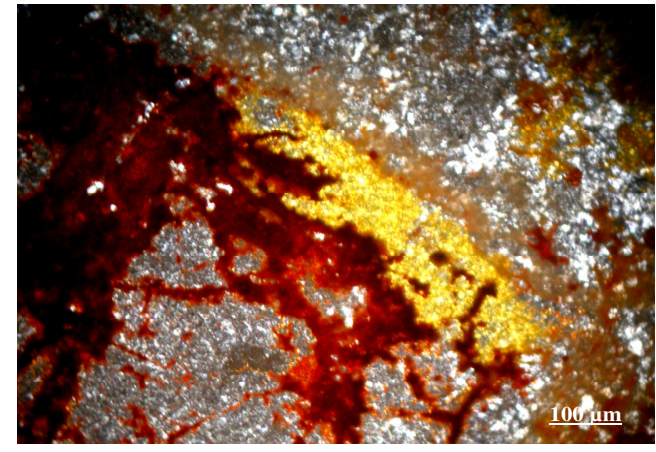

Fig.18: Photomicrograph of radioactive minerals associated with iron oxides in jasperoid vein, XPL

metrically surveyed. Particular attention was paid to all structural features such as contacts and fractures as well as hydrothermally altered zones. The field radiometric measurements (Table 2) indicate that the eU and eTh increase gradually from Nubian Sandstones to granodiorites through syenogranites and reach the highest values in jasperoid fracture filling veins.

Uraniferous rocks are defined as any rock containing uranium at least twice the Clark value (4ppm) according to Darnley (1982). Assaf et al. (1997) concluded that uraniferous granites contain more than $18 \mathrm{ppm}$ uranium. Then, the studied syenogranites can be con-

Table 2 : The eU and eTh contents and eTh/eU ratio of the studied granitoids

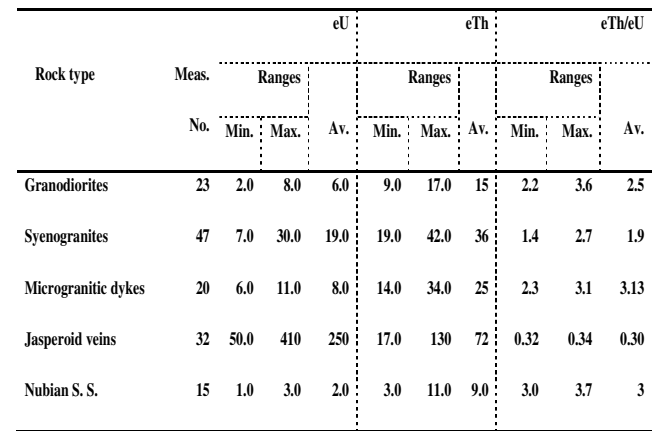


sidered as uraniferous granites.

Generally, the high radioactive anomalies in the study area are recorded in the jasperoid fracture filling veins hosted within the syenogranites. These radioactive jasperoid veins have enrichment with uranium (Table 2).

\section{MINERALOGY}

Due to yellow colored secondary uranium minerals were noticeable in jasperoid fracture filling veins and the surrounded sheared granites. Consequently, some grains were scratched from the surfaces of these samples to be studied by X-ray diffraction and Environmental Scanning Electron Microscope (ESEM) model Philips XL 30, attached with Energy Dispersive X-ray unit (EDX) at the laboratory of the Nuclear Materials Authority (NMA). Analytical conditions are 15-30 kv accelerating voltages, 1-2 Mm beam diameter and 60-120 second counting time.

Other samples were crushed to sandsized fraction and then subjected to heavy liquid separation using bromoform. The heavy mineral fractions are further separated to magnetic and non-magnetic fractions using Frantz Isodynamic Magnetic Separator. The radioactive minerals are picked and identified under the binocular microscope. As well as ESEM, the confirmation of the minerals identifications is done using X-ray dif-

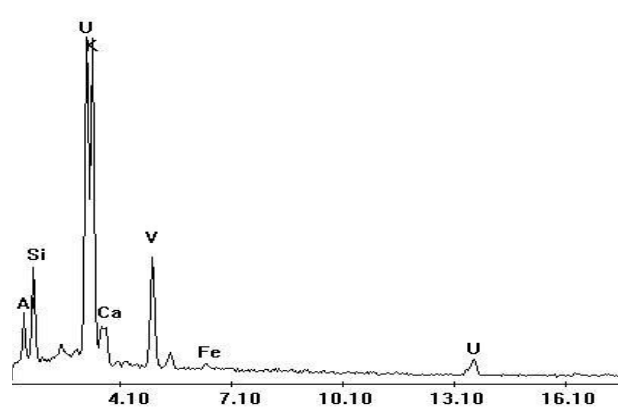

Fig.20: EDX and BSE image of carnotite fraction (XRD) technique. The mineralogical study indicates that the radioactive minerals occurred in jasperoid veins are carnotite and uranophane as secondary uranium minerals besides betafite, samarskite, violet fluorite and zircon as U-bearing accessory minerals.

\section{Uranium Minerals}

\section{Carnotite: $\mathrm{K}_{2}\left(\mathrm{UO}_{2}\right)_{2}\left(\mathrm{VO}_{4}\right)_{2} \cdot \mathbf{3} \mathrm{H}_{2} \mathrm{O}$,}

Carnotite is a hydrated potassium uranium vanadate mineral. It occurs as bright yellow to orange color thin film coating of feldspars (Fig. 19). EDX of carnotite shows the main composition as $\mathrm{U}, \mathrm{K}$ and $\mathrm{V}$ as well as minor components of $\mathrm{Ca}, \mathrm{Fe}, \mathrm{Si}$ and Al. (Fig. 20).

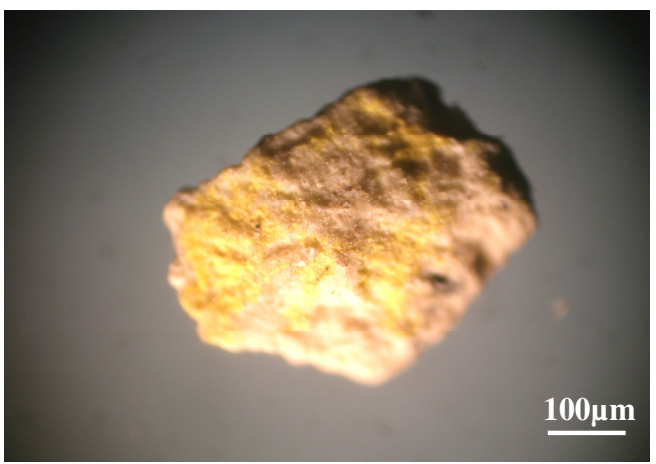

Fig.19: Stereo-photomicrograph showing carnotite

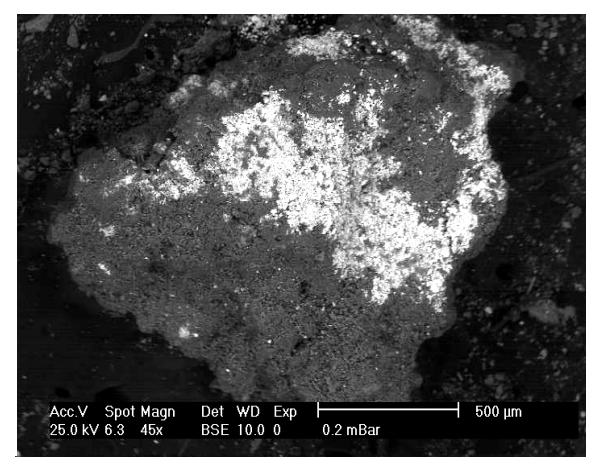




\section{Uranophane: $\mathrm{Ca}\left(\mathrm{UO}_{2}\right)_{2}\left(\mathrm{SiO}_{3}\right)_{2}(\mathrm{OH})_{2} .5$ $\mathrm{H}_{2} \mathrm{O}$}

Uranophane was recorded as secondary uranium minerals. It is varies in color from lemon yellow to straw yellow and occurs as thin flakes or soft aggregates associated with altered feldspars (Figs. 21\&22). EDX shows the main components of the studied uranophane are $\mathrm{U}, \mathrm{Ca}$ and $\mathrm{Si}$ (Fig. 23). FeO is present being probably due to the decomposition of Fe-oxyhydroxides. Secondary enrichment of $\mathrm{Fe}$ in uranophane crystals was reported by Frondel (1958), Heinrich (1958) and Dawood and Abd El Naby (2001). The identification of uranophane is confirmed by XRD analysis (Fig. 24).

\section{Uranium - Bearing Minerals}

Betafite:(Ca, U) ${ }_{2}(\mathrm{Ti}, \mathrm{Nb}, \mathrm{Ta})_{2} \mathrm{O}_{\mathbf{6}}(\mathrm{OH})$

Betafite is a mineral in the pyrochlore group. It is the most U-rich (24-28 wt \%) of $\mathrm{UO}_{2}$ of the $\mathrm{Nb}$-Ta oxides and was in general the first to crystallize. Secondary alteration of betafite has taken place along cracks and is marked chiefly by loss of $\mathrm{Ca}$ and $\mathrm{Na}$, but the alteration apparently has not resulted in mobilization of uranium into the environment (Warner, 2003). The stoichiometric nonmetamict betafite contains higher content of

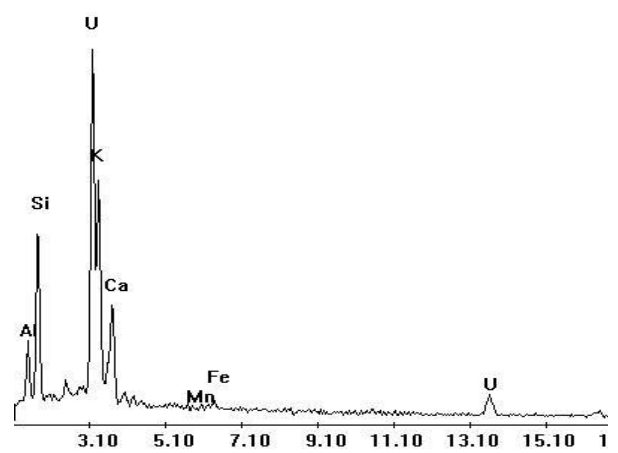

Fig.23: EDX and BSE image of uranophane

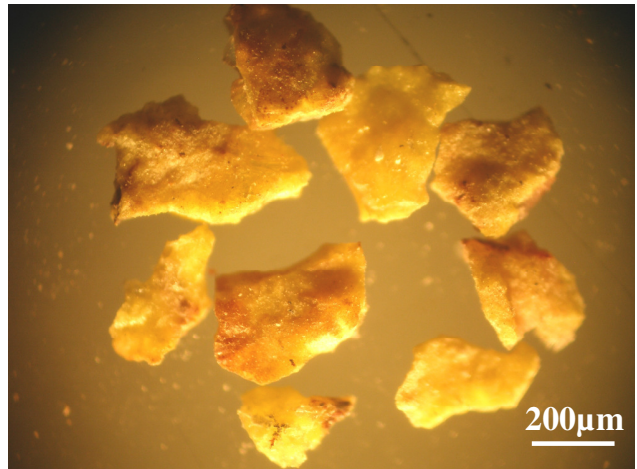

Fig.21: Stereo-photomicrograph showing lemon yellow uranophane

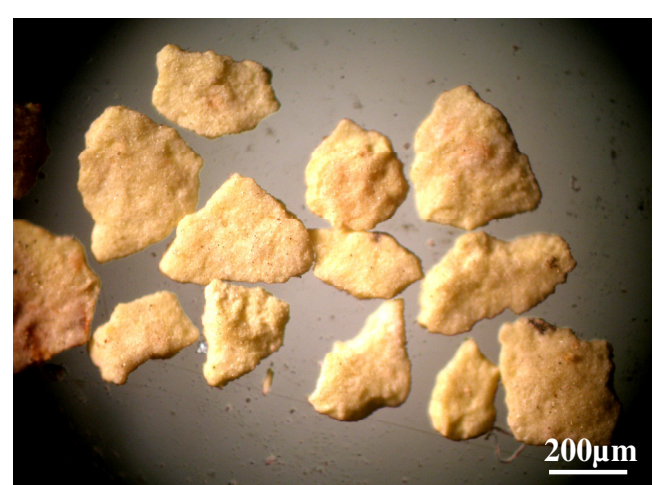

Fig.22: Stereo-photomicrograph showing straw yellow uranophane

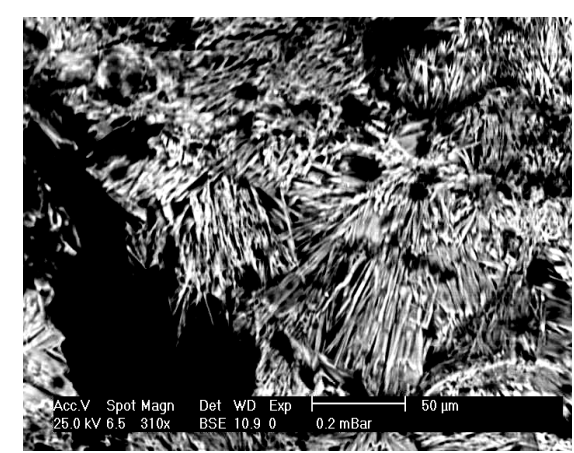




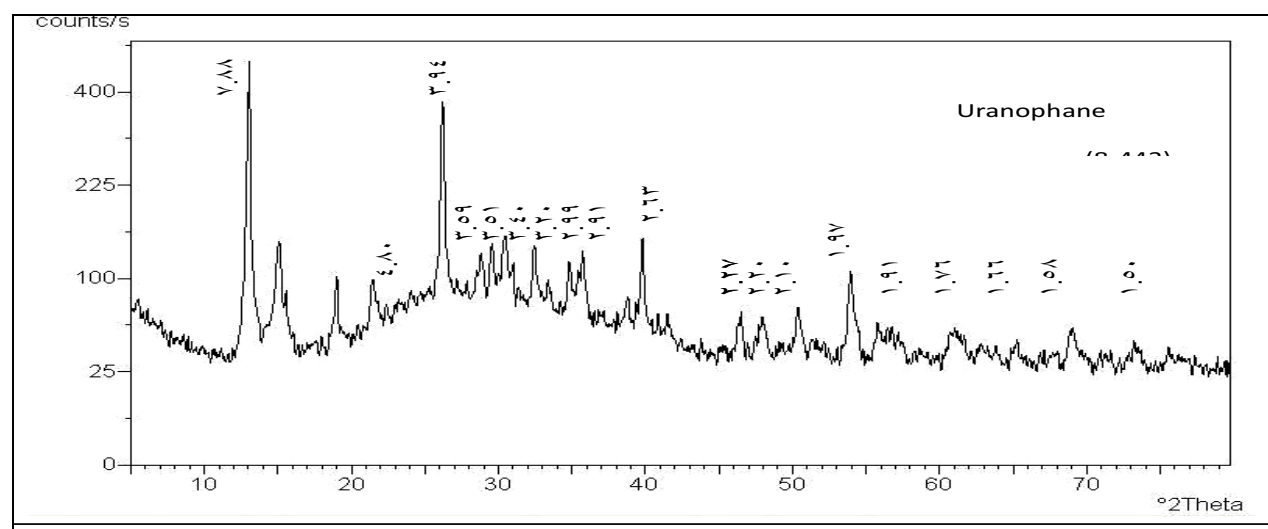

Fig.24: XRD diffractogram of Uranophane

$\mathrm{UO}_{2} \mathrm{wt} \%$ (average of $31.19 \mathrm{wt} \%$ ) (Camara et al., 2004), while the betafite from El-Atshan trachyte give an average of $\mathrm{UO}_{2}=31.23$ wt\% (Abd El Naby, 2009).

Under binocular microscope, the studied betafite crystals are generally massive with granular form having dark brown to black color and vitreous luster (Fig. 25). They are generally translucent, compact, metamict and hard. EDX data show that the studied betafite was enriched with $U$. Other components are present as $\mathrm{Ca}, \mathrm{Ti}, \mathrm{Nb}$, Ta, in addition to $\mathrm{Th}$ and Ce (Fig. 26). The XRD diffractogram of Betafite declares its metamict state due to the

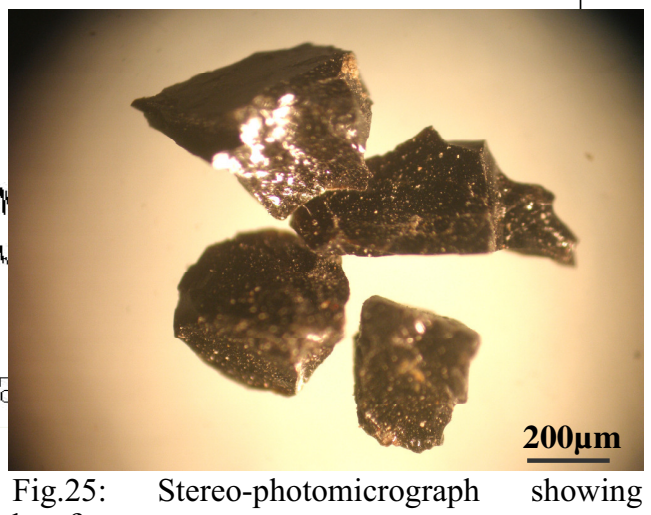

betafite
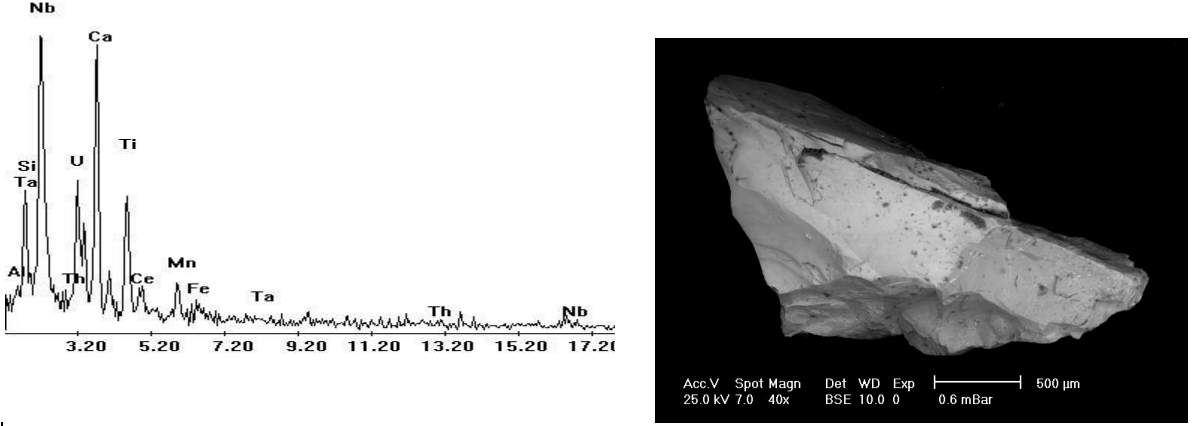

Fig.26: EDX and BSE image of betafite 
presence of significant amounts of uranium and thorium. The sample was heated to 1000 ${ }^{\circ} \mathrm{C}$ for 3 hours for recrystallization of the mineral by heating. The XRD pattern of betafite is shown on Fig. (27).

\section{Samarskite: $(\mathrm{Y}, \mathrm{Ce}, \mathrm{U}, \mathrm{Fe})_{3}(\mathrm{Nb}, \mathrm{Ta}, \mathrm{Ti})_{5}$ $\mathrm{O}_{16}$}

Samarskite crystals are massive, with granular form having velvet black color and resinous luster (Fig. 28). EDX data (Fig. 29) show that the studied samarskite belongs to ishikawite type due to enrichment with $\mathrm{UO}_{2}$
(Hanson et al., 1999).

\section{Fluorite: $\mathrm{Ca} \mathrm{F}_{2}$}

Fluorite has extremely variable colors and many times can be an intense purple, blue, green or yellow, also, colorless, reddish orange, pink, white and brown. A single crystal can be multi-colored. The studied fluorite ranges in color from colorless to violet (Fig. 30). EDX analysis shows the typical composition of fluorite $\mathrm{Ca}$ and $\mathrm{F}$ (Fig. 31). Analysis of violet fluorite shows the presence of $U$, this is agreed with many authors who recorded

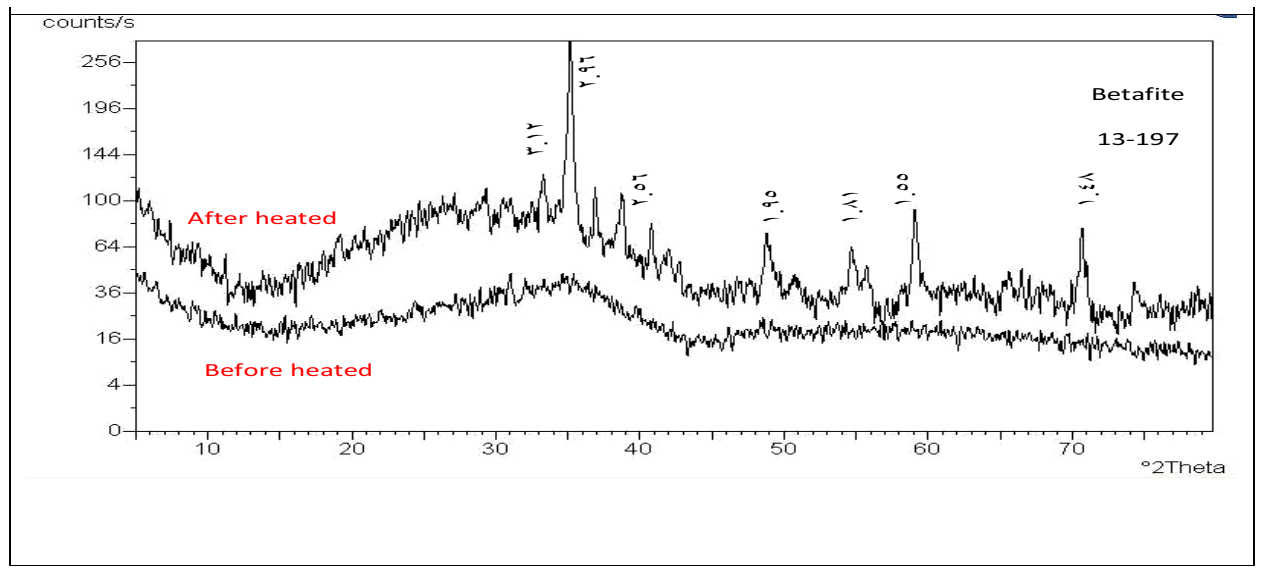

Fig.27: XRD diffractogram of betafite

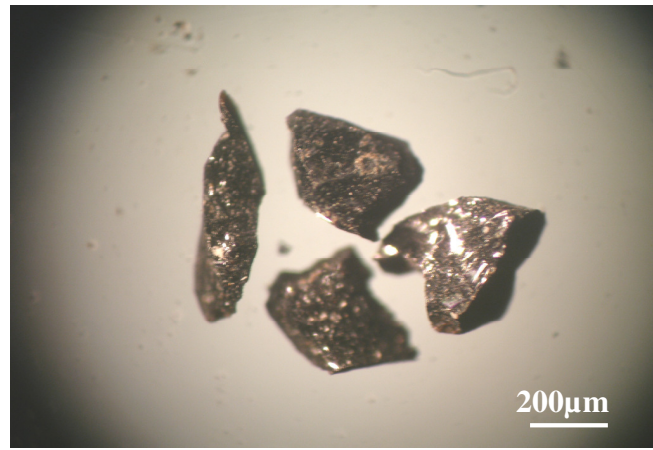

Fig.28: Stereo-photomicrograph showing samarskite that the blue to violet color of fluorite is due to radioactivity (El Mansi, 2000 and Raslan, 2009).

The identification of fluorite is confirmed by XRD analysis (Fig. 32). Fluorite is considered as a persistant mineral most commonly formed under epithermal conditions with range of deposition (Tilsley, 1978). High epithermal fluorites are coarse crystals, non radioactive and of green to blue colors whereas marginal radioactive fluorites are generally low epithermal, shallow, fine grained and of deep violet color. 

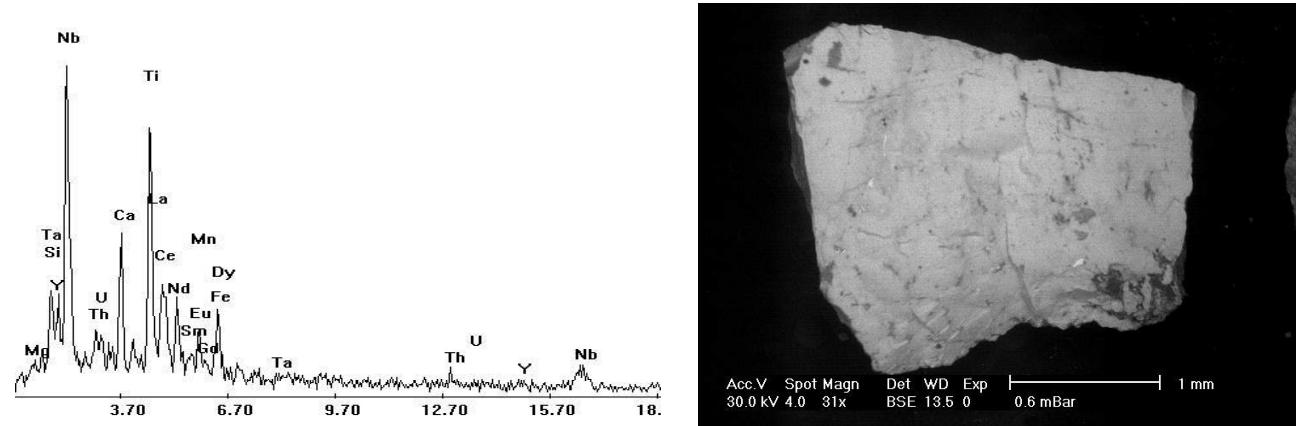

Fig.29: EDX and BSE image of samarskite

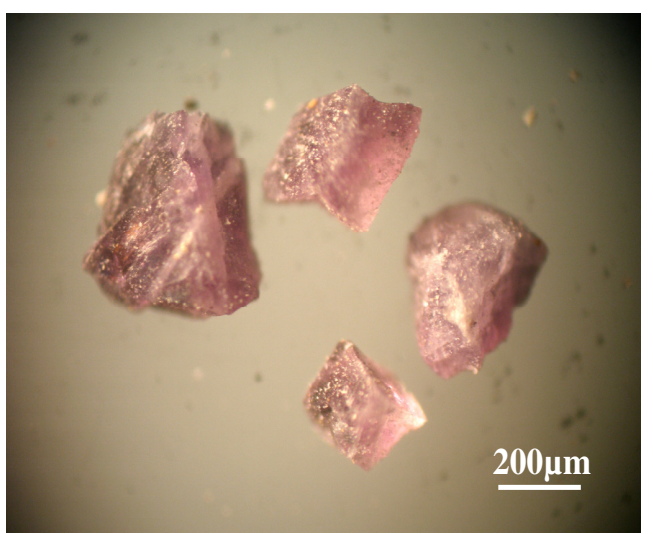

Fig.30: Stereo-photomicrograph showing violet fluorite

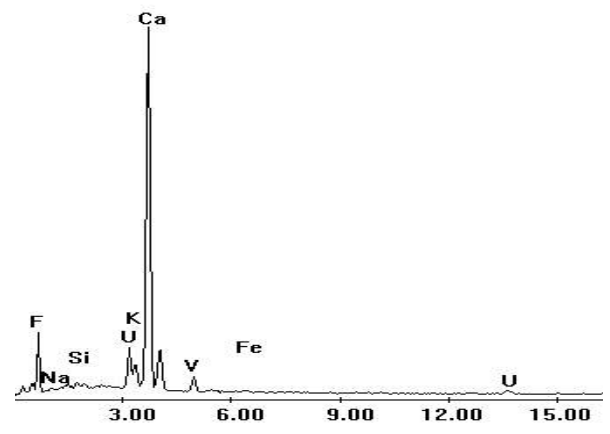

Fig. 31: EDX and BSE image of fluorite

\section{Zircon: $\mathrm{ZrSiO}_{4}$}

Zircon is zirconium silicate with some Hf, U, Th and Y. Their color ranges from colorless to black, where the brown and black colors are due to iron impurities. EDX data was shown on Fig. 33. The identification of zircon is confirmed by XRD techniques (Fig. $34)$.

\section{DISCUSSION AND CONCLUSIONS}

Field and petrographical studies reveals that the study area are represented mainly by granodiorites and syenogranites cutted by acidic microgranite dykes and quartz veins

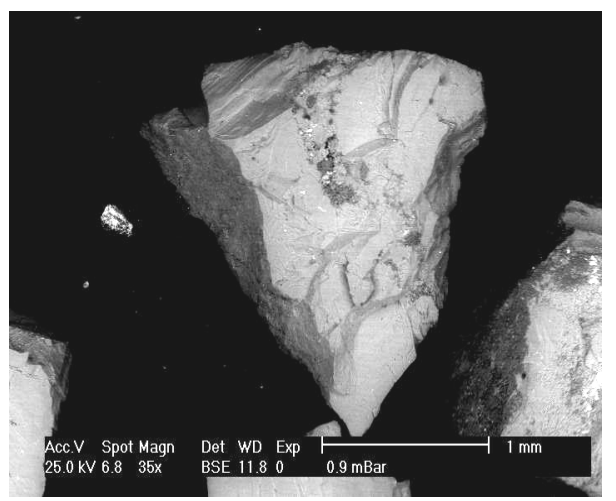




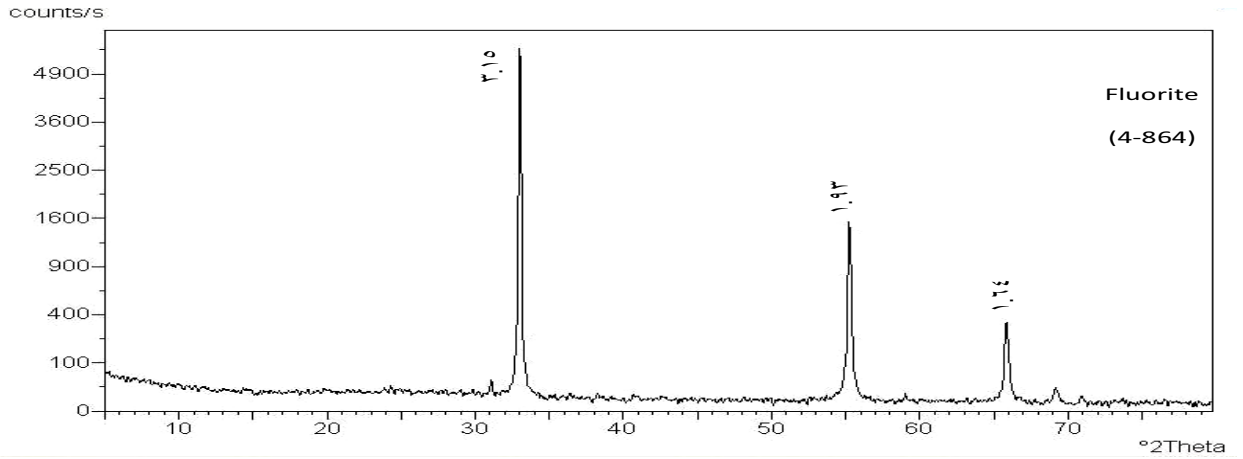

Fig.32: XRD diffractogram of fluorite
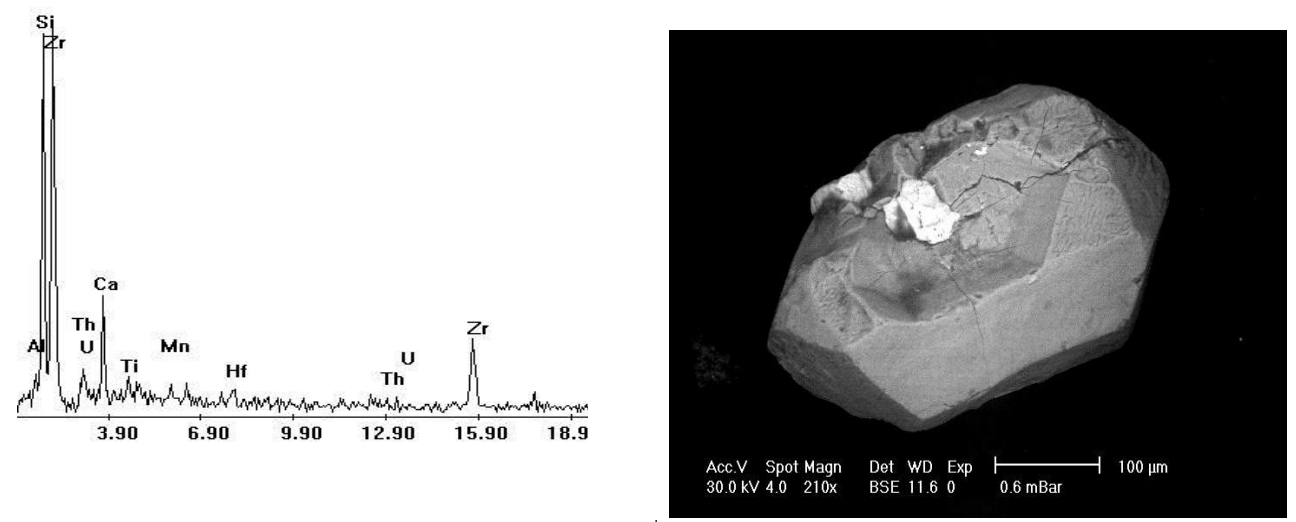

Fig.33: EDX and BSE image of zircon

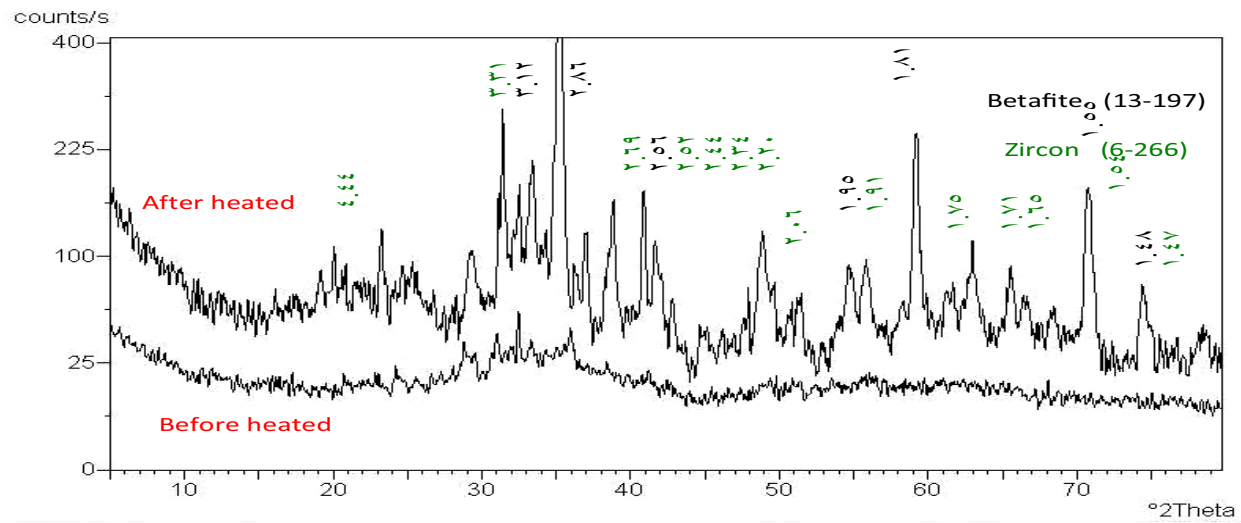

Fig. 34: XRD diffractogram of zircon 
as well as fracture filling jasperoid veins, which are unconformably overlain from the west by Nubian sandstone. The jasperoid veins which are mostly observed at the highly tectonized fractures show enrichment of bright yellow-colored secondary uranium mineralization associated with iron oxides. These associations have conclusive importance for the behavior of trace elements. Kamineini et al (1986) recorded the adsorption of $U$ on ferric oxhydroxide. Also, experimentally hematite has a significant effect on the retardation of $U$ when present in a low proportion as fracture filling (Casas et al., 1994).

Uranium mineralization is associated with the hydrothermally altered parts of the granitic rocks and localized within fractured parts that are filled with jasperoid veins. Alteration near by the jasperoid veins are ferrugination, sericitization, kaolinization, silicification and black dendritic patches of manganese oxides especially along the structural lines. The associated faults represent a good network for the hydrothermal fluids and sites for localizing the mineralization. This is explained by the fact that most of the various U-mineralized occurrences are disposed at the vicinities of the faults.

Radiometric measurements on the studied area show the presence of highly radioactive jasperoid veins hosted within syenogranitic rocks where the average of eU= $250 \mathrm{ppm}$ and $\mathrm{eTh}=72 \mathrm{ppm}$. The enrichment of uranium in the jasperoid veins is probably because of the mobilization of uranium from the syenogranite. This conclusion is supported by relatively high uranium content of syenogranite (eU=19ppm on average), whereas the normal uranium content of granite is typically 4ppm (Cuney, 1978 and Kobranova, 1989 ) and up to 11.5 ppm (Stuckless and Ferreira, 1976). This is agree with many previous studies that proved the importance of jasperoid veins as host for radioactive minerals in the Egyptian Eastern Desert (El-Kammar et al., 1997, Abu Deif and El Tahir, 2008, Abd El Naby, 2008 and Raslan, 2009).
Detailed microscopic examinations, X-ray diffraction (XRD) and Environmental Scanning Electron Microscope (ESEM) with EDX analysis revealed the presence of secondary uranium minerals as carnotite and uranophane as well as U-bearing accessory minerals such as betafite, samarskite, zircon, violet fluorite and iron oxides.

The secondary uranium can be subdivided into three types: (1) absorbed U in altered minerals such as montorillonite, chlorite and limonite (metasomatism). (2) interstitial uranium at grain boundaries which formed as a result of hydrothermal solution migration along the interstices of minerals in rocks (hydrothermal alteration). (3) uranium in microfractures, the formation of this kind of uranium takes place during the circulation of hydrothermal solutions after the deformation of rocks (weathering alteration).

The possible complexes of $\mathrm{U}^{6+}$ in the oxidation state are uranyl fluoride, uranyl phosphate, uranyl carbonate and uranyl ions. The apatite and calcite are not present in the studied jasperoid vein, so, carbonate and phosphate complexes could be excluded. The intimate association of uranophane and fluorite may indicate the probable complexing of $\mathrm{U}^{6+}$ by fluoride anion $\left(\mathrm{UO}_{2} \mathrm{~F}^{3-}\right)$. Longmuir (1978) stated that uranyl $\mathrm{U}^{6+}$ fluoride complexes are readily soluble under acidic condition. Once complexed, these fluids would be transported through fractures and shear zones until they were decomplexed because of mixing of acid uranium-bearing solutions with ground water, resulting in the formation of carnotite, uranophane and violet fluorite. Silica required for these mineralizations was primarily carried by the hydrothermal fluids with contribution from silica released from the granitic rocks as a result of alteration. Therefore, Uranium mineralization was formed by precipitation of uranium and associated cations from the hydrothermal fluids that formed the jasperoid veins in sheared and fractured zones.

The fact that $\mathrm{F}$ may play a prominent role in the hydrothermal mobilization of HFSE has 
been indicated for $\mathrm{Zr}$ and REE (e.g. Moine and Selvi, 1999 and Ibrahim et al., 2004). The detected zircon of demonstrably hydrothermal origin can be attributed to the role of F-rich fluid.

\section{REFERENCES}

Abd El Naby, H. H., 2008. Genesis of secondary uranium minerals associated with jasperoid veins, El Erediya area, Eastern Desert, Egypt. Miner. Deposita, 43, 933-944.

Abd El Naby, H. H., 2009. Role of geochemical alteration on the formation of secondary $\mathrm{Zr}$ and U-bearing minerals in El Atshan trachyte, Central Eastern Desert, Egypt. J. Mineral. and Petrol. Sciences, 104, 37-51.

Abdel-Monem, A. A., and Hurley, P. M., 1979. U$\mathrm{Pb}$ dating of zircons from psammitic gneisses, Wadi Abu Rusheid-Wadi Sikait area, Egypt. Ins. Appl. Geol., King Abdull Aziz Univ. Jeddah, Bull.2, 45-55.

Abu Deif, A., and El Tahir, M., 2008. A new uranium occurrence, Gabal El Missikat prospect, central Eastern Desert, Egypt. JKAU, Earth Sciences, 19, 85- 97.

Abu Deif, A.; El Husseiny, M. O.; El Balakssy, S. S., and Abu Zeid, E. K., 2007. Wall rock alteration and uranium mineralization at M-III uranium occurrence, Gabal El Missikat younger granites, central Eastern Desert, Egypt. $2^{\text {nd }}$ Inter. Conf. Geol. Tethys, Cairo Univ., 647-654.

Abu El Leil, I. A., 1980. Geology, petrography and geochemistry of some granitic rocks in the northern part of the basement complex, Egypt. Ph. D. Thesis. Al- Azhar Univ., 294p.

Assaf, H. S.; Mahdy, M. A., and El Afandy, A. H., 1997. Egyptian younger granites, an approach to define parameters favouring formation of uranium deposits. $3{ }^{\text {rd }}$ Conf. Geochem., Aexandria Univ., 409-420.

Camara, F.; Williams, C. T.; Della Ventura, G.; Oberli, R., and Caprilli, E., 2004. Non metamict betafite from Le Carcarelle (Vico vol- canic complex, Italy); occurrence and crystal structure. Miner. Mag., 68, 939-950.

Casas, I.; Casabona, D.; Duro, L., and Depablo, J., 1994. The influence of hematite on the adsorption of uranium (VI) onto granite filling fractures. Chem. Geol., 113, 319-326.

Cuney, M., 1978. Geologic environment, mineralogy and fluid inclusions of Boisnoirs Limmouzat uranium vein, Froez, France. Econ. Geol., 73, 1567-1610.

Dardir, A. A. and Abu Zeid, K. M., 1972. Geology of the basement rocks between latitude $27^{\circ}$ 00 and $^{\circ} 27^{\circ} 30^{`}$ N, Eastern Desert, Egypt. Ann. Geol. Surv. II, 129-159.

Darnley, A. G., 1982. Hot granites, Some general remarks, In: uranium in granites (Maurice, Y. J., Ed.) . Geol. Surv. Canada, paper 81-23,110.

Dawood, Y. H., and Abd El Naby, H. H., 2001. Mineralogy and genesis of secondary uranium deposits, Um Ara area, South Eastern Desert, Egypt. J. Afri. Earth Sciences, 32 (2), 317-323.

Dixon, T. H., 1979. The evolution of continental crust in the late Precambrian Egyptian Shield. Ph. D. Thesis, California Univ., U. S. A. ,230p.

El-Galy, M. M.; El-Kholy, D. M.; Abdel-Aty, M. A. M., and Khamis, H. A., 2000. Pan-African younger granites of Wadi Hammad area, North Eastern Desert, Egypt; Geological, geochemical and radioactivity evolution. Egypt. J. Geol. , 46/1, 21-38.

El-Kammar, A. M.; El-Hazik, N.; Mahdy, M., and Aly, N., 1997. Geochemistry of accessory minerals associated with radioactive mineralization in the central Eastern Desert, Egypt. J. Afri. Earth Sciences, 25 (2), 237-252.

El-Mansi, M. M., 2000. Coloration of fluorite and its relation to radioactivity. Egypt. Miner. 12, 93-106.

El-Ramly, M. F., and Akaad, M. K., 1960. The basement complex in the central Eastern Desert of 
Egypt between latitude $24^{\circ} 30^{`}$ and $25^{\circ} 40^{\prime} \mathrm{N}$. Geol. Surv. Egypt., paper. 8, 15p.

Frondel, C., 1958. Systematic mineralogy of uranium and thorium. U. S. Geol. Surv. Bull, 1064-1400.

Fullagar, P.D., and Greenberg, J. K., 1978. Egyptian younger granites. A single period of plutonism.(abs.). Precamb. Res., 6, A22.

Ghanem, M.; Dardir, A. A.; Francis, M. H.; Zalata, A. A., and Abu Zeid, K. M., 1973. Basement rocks in Eastern Desert of Egypt north of latitudes $26^{\circ} 40$. Ann. Geol. Surv. Egypt. ,III, 33-38.

Hanson, S.L.; Simons, W.B.; Falster, A.U.; Foord, E.E., and Lichte, F. E., 1999. Proposed nomenclature for samarskite-group minerals; new data on ishikawaite and calciosamarskite. Mineral. Mag., 63, 27-63.

Heinrich, E. W., 1958. Geology of radioactive raw materials. McGraw- Hill, New York, 654p.

Ibrahim, I. H.; Abd El Wahed, A. A., and Ali, M. A., 2004. Mineralogical and spectrometric studies of El-Sibai shear zone, Central Eastern Desert, Egypt. $6^{\text {th }}$ Intern. Conf. Geochemistry. Alexandria Univ., Egypt.

Kamineini, D. C.; Chung, C. F.; Dugal, J. J. B., and Ejeckam, R. B., 1986. Distribution of uranium and thorium in core samples from the underground research laboratory Lease area, outheastern Manitoba. Can. Chem. Geol., 54, 97-111.

Khamis, H. A., 1995. Radioactivity and structure of Wadi Hammad area, North Eastern Desert, Egypt.. M. Sc. Thesis. Cairo Univ. Cairo. Egypt.

Kobranova, V. N., 1989. Petrophysics. Springer,
Berlin, Heidelberg, New York, 375p.

Langmuir, D., 1978. Uranium solution-minerals equilibria at low temperatures with applications to sedimentary ore deposits. Geochim Cosmochim. Acta, 42,547-569.

Moine, B., and Selvi, S., 1999. Role of fluorine-rich fluids in hydrothermal transport of immobile elements (Th, Zr, REE). Bull. De Liaison de la Societe Francaise de Mineralogie et de Cristallographie (S. F. M. C.), 11, 90-92.

Mussa, M. A., and Abu El Leil, I., 1983. Structural analysis as a guide to mineralization trends in the North Eastern Desert of Egypt. Ann. Geol. Surv. Egypt., XIII, 271-276.

Raslan, M. F., 2009. Mineralogical and geochemical characteristics of uranium-rich fluorite in El-Missikat mineralized granite, Central Eastern Desert, Egypt. Geologija, 52(2), 213-220.

Schurmann, H. M. E., 1953. The Precambrian of the Gulf of Suez area. 19 $9^{\text {th }}$ Inter. Geol. Cong. Algeria, Sec., 1, 115-135.

Streckeisen, A., 1976. To each plutonic rocks its proper name. Earth Science Rev., 12, 1-33.

Stuckless, J. S., and Ferreira, C. P., 1976. Labile uranium in granitic rocks. Proc. symposium on exploration of uranium ore deposits. IAEA, Vienna, 208-217.

Tilsley, J. E., 1978. Uranium mineralization in shallow intrusive environments, short course in uranium deposits. Mineral Ass. Canada, 281292.

Warner, R. D., 2003. Uranium minerals at Maw Bridge pegmatite Near Central, South Carolina, Seattle Annual Meeting, paper number 254-7. 


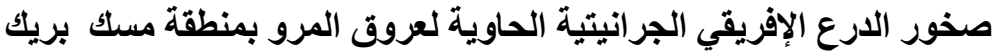

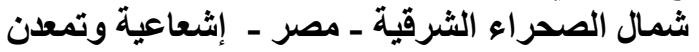

\author{
سعيد سيد فرج، محمد عمر الحسيني و صلاح صبحي البلاقصى
}

اعتمادا على العلاقات الحقلية والدراسات البتروجر افية أمكن تقسيم الصخور الجر انيتية بمنطقة الدر اسة

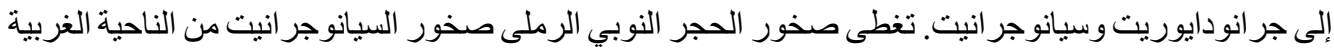

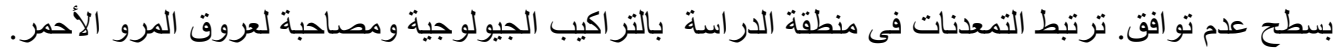

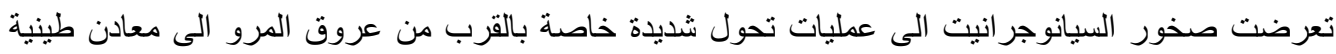

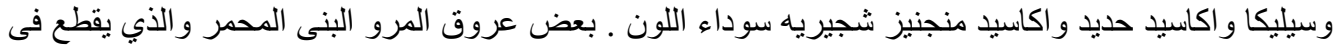
صخور السيانوجر انيت وخاصة في مناطق التكسير الثديد تحتوى على بقع صفر اء من معادن اليور انيوم الثانوية

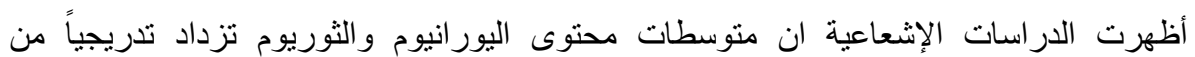

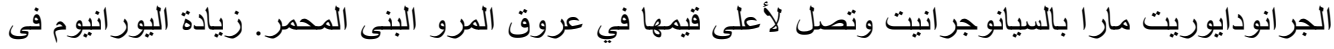

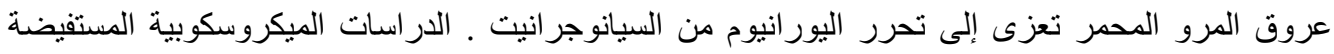

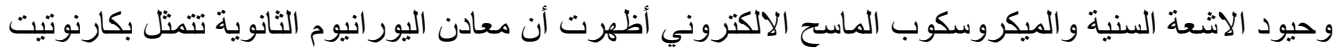

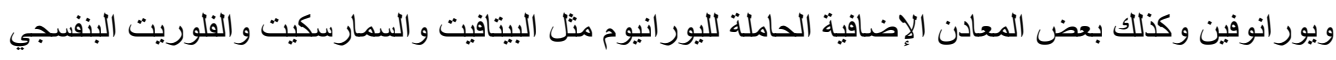

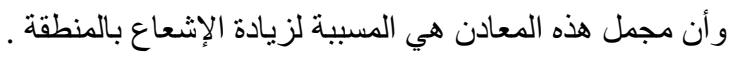

